\title{
Strategic entrepreneurship behaviour and the innovation ambidexterity of young technology-based firms in incubators
}

International Small Business Journal: Researching Entrepreneurship 202I, Vol. 39(3) 202-227 (C) The Author(s) 2020

(c) (i)

Article reuse guidelines: sagepub.com/journals-permissions DOI: I0.I I 77/0266242620943776 journals.sagepub.com/home/isb

\section{Mathew Hughes $i D$ \\ Loughborough University, UK}

\section{Paul Hughes}

De Montfort University, UK

\section{Robert E Morgan}

Cardiff University, UK

\section{lan $\mathbf{R}$ Hodgkinson}

Loughborough University, UK

\section{Younggeun Lee $\mathrm{iD}$}

California State University, Los Angeles, USA

\begin{abstract}
Innovation ambidexterity is especially complex for young technology-based firms because they are resource-challenged and knowledge deficient in strategic terms; but they possess considerable scope for entrepreneurship. Strategic entrepreneurship may provide a solution. Incubators emerged as a policy solution precisely due to this dilemma. We conceptualise that strategic entrepreneurship, as a synthesis of opportunity-seeking and advantage-seeking behaviours of young technology-based firms, can affect both explorative and exploitative innovation activities in these firms and expect that subsequent innovation ambidexterity affects profitability. Our empirical analyses reveal complex and competing interrelationships that both ease and exacerbate the tensions associated with innovation ambidexterity. We contribute to theory by testing strategic entrepreneurship as it applies to innovation ambidexterity and evidence behaviours that contribute to its foundations. To entrepreneurs and managers, we offer a set of prescriptions
\end{abstract}


for innovation ambidexterity in young firms that accounts for the complementarities between complex and theoretically opposing constructs.

\section{Keywords}

business incubation, entrepreneurial orientation, exploitation, exploration, incubators, innovation ambidexterity, resources, strategic entrepreneurship, young firms

\section{Introduction}

Young technology-based firms face two fundamental challenges connected to their liabilities of newness. The first is to effectively and efficiently exploit in-house capabilities to create revenue streams and manage cost structures. The second is exploring new innovations to overcome the rapid development of new technology and the short life-cycle of many technology products and services caused by intense industry competition (Tukker and Tischner, 2017). For young technology-based firms, this situation calls for innovation ambidexterity (Hughes et al., 2021; Volery et al., 2015; Voss et al., 2008; Voss and Voss, 2013), defined as the high-quality, simultaneous balance (Simsek, 2009) of exploitation and exploration activities. Ambidexterity is necessary to increase the efficiency of processes, improve operations management and create value that may eventually help these firms to attain legitimacy, accountability, reliability and short-term sustainability (exploitation); while also pursuing new opportunities and building creative services and products for medium-to-long-term viability in the face of rapid technology development driven by intense competition in technology industries (exploration).

Yet, both of these activities are at odds with each other (March, 1991). Too much exploitation, and the young firm strengthens its burgeoning capabilities into a rigid state, losing its ability to innovate; too much exploration, and the young firm risks becoming unsustainable, trapped in neverending technology development but little market development (Hughes, 2018; Levinthal and March, 1993). In fact, young technology-based firms have the capacity to regularly detect new opportunities for new technologies and innovations, but are far less effective at compiling the capabilities and resources needed to generate revenue streams to secure their future (Arzubiaga et al., 2018; Ireland and Webb, 2007, 2009; Kollmann and Stöckmann, 2014). A potential solution lies in strategic entrepreneurship: the extent to which a firm marries opportunity-seeking and advantage-building behaviours (Kuratko and Audretsch, 2013; Mazzei et al., 2017; Withers et al., 2018).

Critics point to potentially insurmountable challenges and substantial implementation problems (Nosella et al., 2012; Stettner and Lavie, 2014; Walrave et al., 2017) for those seeking innovation ambidexterity. While crucial to the performance and longevity of young technology-based firms, these firms are resource and knowledge deficient, often with underdeveloped capabilities, and current solutions to achieving ambidexterity are largely grounded in studies of far larger and established firms. At the heart of this problem has been a failure to conceptualise the antecedents and organising principles of ambidexterity (Durisin and Todorova, 2012; Koryak et al., 2018; Wilden et al., 2018) and an especial neglect for the context in which exploration and exploitation take place (Khan et al., 2018; O'Reilly and Tushman, 2013; Stettner and Lavie, 2014). As highlighted by Koryak et al. (2018), 'while some common antecedents of ambidexterity as an overarching construct have been identified . . . its constituent components - exploration and exploitation - tend to be associated with diametrically opposing factors' (p. 414). Which conditions shape this exploration-exploitation interplay is perhaps the most persistent criticism levelled against the ambidexterity thesis (Burgess et al., 2015; Koryak et al., 2018), and current treatments do not sufficiently 
examine how the momentum for explorative or exploitative innovations may derive from related firm activities (Mom et al., 2019).

We address this research opportunity in two ways. First, explorative and exploitative innovations are two competing, but essential, activities young technology-based firms must reconcile (Tushman and O'Reilly, 1996). Drawing on strategic entrepreneurship, we examine how strategic and entrepreneurial behaviours create tendencies that favour one innovation activity over the other, or, are common to both. Young technology-based firms with limited resources and liabilities of newness use different capabilities to implement explorative and exploitative innovations (Feng et al., 2019; Heavey et al., 2015). Firms pursuing strategic entrepreneurship seek new opportunities (opportunity-seeking behaviour) either to expand current product offerings by refining burgeoning competences (with exploitative innovation) or to adventure into new product domains (with explorative innovation) by remodelling its resource base (advantage-seeking behaviour) to compete on both market and technology frontiers (Kollmann and Stöckmann, 2014; Mazzei, 2018; Simsek et al., 2017; Withers et al., 2018). This application corrects for the disregard among studies of innovation ambidexterity for the organising principles underpinning both innovation forms (Birkinshaw and Gupta, 2013; Durisin and Todorova, 2012; O’Reilly and Tushman, 2013) and allows us to examine what activities augment exploration, exploitation or both. Second, to correct for the common disregard of context among studies of innovation ambidexterity of firms (Junni et al., 2020; Stettner and Lavie, 2014), we choose a context in which the complexity of managing scarce resources and firm entrepreneurship are exacerbated. We focus on young technology-based firms located in incubators where the challenges to achieving a sustainable future are particularly acute (Deligianni et al., 2019; Tukker and Tischner, 2017). In young technology-based firms, excellence at seeking opportunities is counterbalanced by inadequate resource ownership needed to generate and sustain longer term viability (Tornikoski et al., 2017). Incubators are a popular policy tool because they enable young technology-based firms to engage in entrepreneurial ecosystems (Bank et al., 2017; Lasrado et al., 2016; Spigel, 2017) to network with other technology firms and partners to close resource gaps and overcome knowledge deficits that underpin liabilities of newness. Most incubators have a specific focus on technology (Hughes et al., 2007; OECD, 1999). Because young technology-based firms often need significant upfront financial capital and periods of technological development to refine their initial technology in the market place while also creatively innovating to keep up with or surpass intense industry competition, incubators offer a valuable proposition to young technology-based firms by providing access to networks, services and capital (Chan and Lau, 2005). We predict that the firms that best channel strategic entrepreneurship will be those that gain the most from this context and achieve profitability. Our research question is: what strategic and entrepreneurial behaviours favour explorative innovation over exploitative innovation (and vice versa) or favour both?

We provide three contributions. First, we develop and provide a theoretical logic that reveals the strategic entrepreneurship conditions that precipitate explorative and exploitative innovation activities. In doing so, we provide a novel theoretical rationale and model of innovation ambidexterity in which seemingly opposing dimensions of strategic entrepreneurship - being opportunity-seeking and advantage-seeking - and innovation theory co-align in young technology-based firms. Second, we ground our theoretical narrative context sensitively to incubating technology-based firms, correcting for the tendency to relegate context to a mere control variable in entrepreneurship (Zahra et al., 2014), entrepreneurial orientation (EO) (Yin et al., 2020) and ambidexterity (Khan et al., 2018; O'Reilly and Tushman, 2013; Stettner and Lavie, 2014) studies. Collectively, these contributions provide novel theorising and empirical evidence of strategic entrepreneurship as it applies to innovation ambidexterity for incubating technology-based firms. These set essential new building blocks for further scholarly research into the antecedents of innovation ambidexterity as 
called for by Birkinshaw and Gupta (2013), Kassotaki et al. (2019) and O'Reilly and Tushman (2013). Third, we advance the conceptualisation of strategic entrepreneurship to resolve the ambiguity that surrounds exactly what represents opportunity- and advantage-seeking behaviour as lamented by Simsek et al. (2017). To entrepreneurs and managers, we offer a set of behavioural prescriptions for innovation ambidexterity in incubating technology-based firms.

\section{Theoretical framework}

\section{Innovation ambidexterity and young technology-based firms in incubators}

Ambidexterity rose to prominence from March's (1991) seminal work on the fundamental adaptive challenge facing firms (Hughes, 2018). This challenge is conceptualised as the need to both exploitatively refine in-house competencies to grow current revenue streams and manage cost structures while providing for adequate exploration to prepare new technological changes and shape new innovations for future viability (O'Reilly and Tushman, 2013). Exploitative innovation is based on incremental additions, new refinements and cost improvements to existing products and technologies. Explorative innovation is based on new technological possibilities and creative ideas to shape new and truly distinct products. Firms that pursue both innovation activities successfully can align the needs of today's customers while preparing for future markets (Gibson and Birkinshaw, 2004) and potentially obtaining superior business performance (He and Wong, 2004; Hughes, 2018). Those that do not, or do so badly, risk mediocrity or failure. This problem is especially acute for incubating technology-based firms because of rapid changes in technology, short product life-cycles and intense competition (Traynor and Traynor, 2004; Tukker and Tischner, 2017).

In theory, explorative innovation relies on variance-inducing activities at the firm level that fuel the play, discovery and experimentation of new product and technology possibilities, while exploitative innovation relies on choice-inducing activities to fuel the refinement, efficiency and execution of better 'but not new' product and technology possibilities (March, 1991). This dichotomy manifests a significant managerial problem for incubating technology-based firms because both activities compete for scarce resources (Voss et al., 2008) and typically rely on different resource-based and entrepreneurial activities (Ireland and Webb, 2007). This problem greatly affects young technology-based firms because of their relative constraints of newness (Hughes et al., 2014). The result is that one form of innovation tends to flourish, while the other flounders (Voss et al., 2008). Strategic entrepreneurship may resolve this problem (Hitt et al., 2011; Withers et al., 2018).

\section{Strategic entrepreneurship and innovation in incubating technology-based firms}

Two contrasting behaviours drive strategic entrepreneurship: opportunity-seeking behaviour and advantage-seeking behaviour. Conceptualisations of strategic entrepreneurship predict that integrating these two behaviours generates innovation as a precursor to profitability (Ireland et al., 2003). Strategic entrepreneurship involves behaviours in some way intended to fuel or create new or improved forms of revenue and competitive advantage (Mazzei, 2018; Simsek et al., 2017). Opportunity-seeking behaviour is a function of the entrepreneurial strategy of the firm. Through entrepreneurial behaviours, the firm is expected to develop competency at identifying a stream of rich opportunities to fuel innovation (Ireland et al., 2003; Ireland and Webb, 2007, 2009). However, opportunities alone cannot create innovation as this is also dependent on the resources attracted to the firm (Ketchen et al., 2007; Yin et al., 2020). 
Following Ireland et al. (2003), we view opportunity-seeking behaviour as a product of an entrepreneurial mindset and entrepreneurial leadership within a firm. We conceptualise this as the EO of the incubating technology-based firm. ${ }^{1}$ EO captures the mindset, behaviours and accompanying processes that managers use to seek out and pursue novel opportunities (Hughes and Morgan, 2007; Lumpkin and Dess, 1996). An EO embraces entrepreneurial behaviours related to product and market innovativeness, risk-taking and proactiveness (Covin and Slevin, 1989; Miller, 1983). Innovativeness characterises a willingness to depart from current practices and try out new or different ideas. Risk-taking represents the degree to which members of the firm are willing to make resource commitments towards projects that bear uncertainty and exhibit a reasonable danger of costly failure. Proactiveness is a firm-wide mentality to anticipate and act in advance of future problems and opportunities.

Despite these compelling entrepreneurial behaviours, EO remains a first-order effect in pursuing innovation (Arunachalam et al., 2018). Translating entrepreneurial opportunities into productive market offerings requires resources. Ireland et al. (2003) describe this as advantage-seeking behaviour in a construct conceptualised as 'managing resources strategically'. Incubating technology-based firms possess little slack in their in-house competences and resources as these would ordinarily be directed primarily towards the exploitation of existing technology that forms the basis of its first products. This is consistent with the notion that young technology-based firms locate to incubators because of growth aspirations. However, it is also precisely because such young technology-based firms have significant upfront capital requirements and a need to continuously enhance and renew their technologies and products given rapid technology shifts and short product life-cycles, that incubators emerged as a support solution (Hughes et al., 2007; Lasrado et al., 2016; Spigel, 2017). Increasingly, the resources young technology-based firms need to attain profitability and sustain their viability lie outside of the firm's boundaries (Cai et al., 2014). For incubating technology-based firms, this is necessarily so due to resource deficits. Although incubators vary (Theodoraki et al., 2018), they offer access to networks through which resources, services and capital to support the incubating firm can be found (Chan and Lau, 2005). Research suggests that those incubating firms that orient their behaviour to capitalise on such relational resources made accessible through incubators can experience a range of improvements in business performance (Hughes et al., 2007).

Young technology-based firms are typically skilled at identifying abundant and novel entrepreneurial opportunities but are less skilled at assembling and coordinating the resources needed to exploit those opportunities due to liabilities of age and firm size (Lubatkin et al., 2006; Voss et al., 2008; Voss and Voss, 2013). These firms start with low resource stocks that direct advantageseeking behaviour towards resource attraction and acquisition activities, commonly through relationships (Feng et al., 2019; Heavey et al., 2015), to offset their newness and size disadvantages. The incubator provides the platform or ecosystem for this behaviour. Incubating technology-based firms can make extensive use of relational resources to fill gaps in their resource portfolio, changing their constraints (Pfeffer and Salancik, 1978). Thus, we conceptualise the first aspect of advantage-seeking behaviour as accessing and acquiring relational resources. The second aspect of this advantage-seeking behaviour is the firm's relational embeddedness within its network of ties. Higher relational embeddedness is associated with a greater preponderance of strong ties. The quality of social relations, in general, improves with greater relational embeddedness and acts as a mechanism for knowledge transfer (Inkpen and Tsang, 2005) needed to offset the knowledge deficits of young technology-based firms. This knowledge can affect innovation activity (Dittrich and Duysters, 2007).

Squaring strategic entrepreneurship with innovation ambidexterity is difficult because simultaneous entrepreneurial and strategic behaviour can create bimodal effects on innovation activity. 


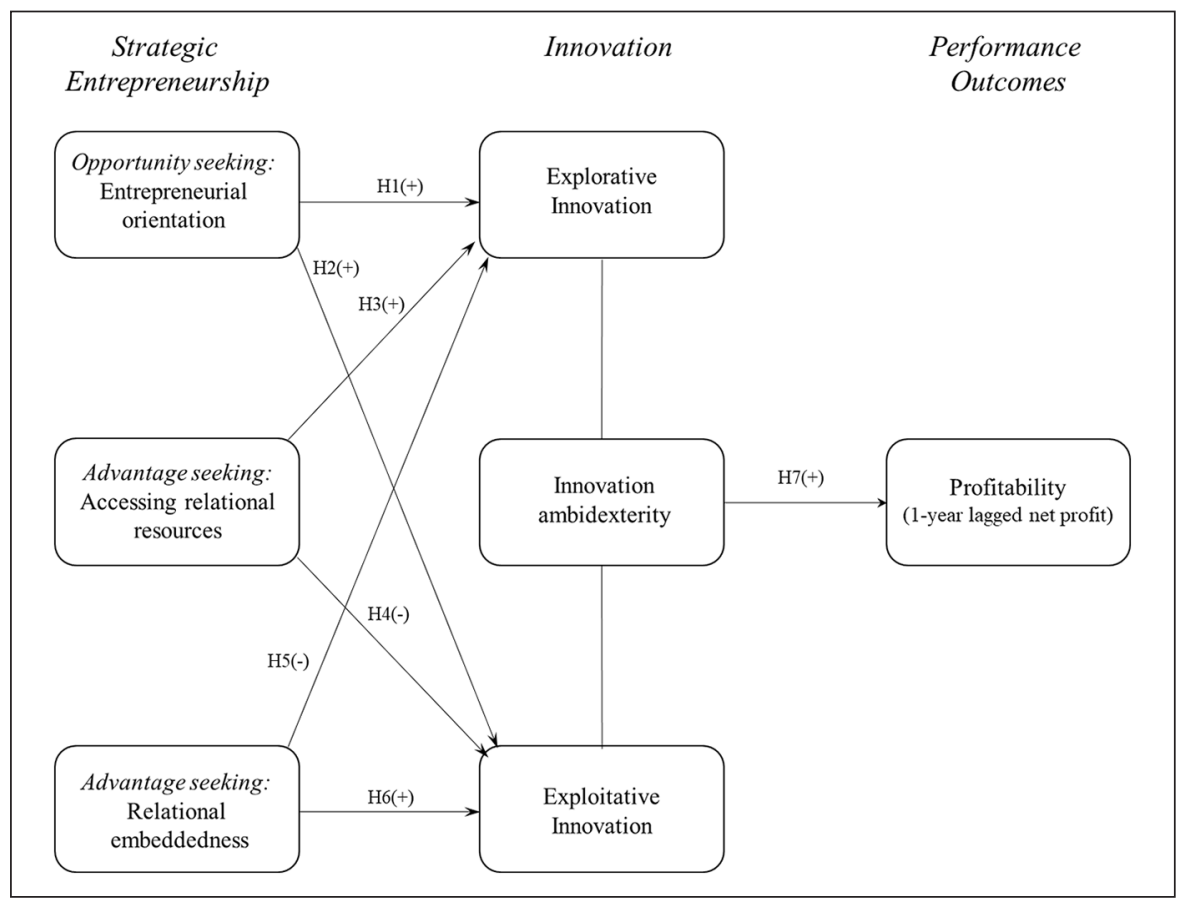

Figure I. Theoretical framework and hypothesised relationships.

For example, Voss et al. (2008) found that resourcing difficulties and insufficient resource slack led young firms to prioritise exploitative innovation activity, but this switched to exploration when new resources entered the young firm. The behaviours associated with strategic entrepreneurship may then exert a mixture of competing and complementary effects on exploration and exploitation as the underlying components of innovation ambidexterity. Young technology-based firms adept at both can better service existing markets with refined product offerings while developing new technology spaces. Under these circumstances, the mediocrity proposed by March (1991) should not arise.

Incubating technology-based firms with EO and a collaborative orientation can, therefore, set the foundations for strategic entrepreneurship to pursue innovation activities. The strategic entrepreneurship paradigm proposes that EO and accessing relational resources strategically are antecedents to explorative and exploitative innovations, which jointly have the potential to increase profitability. Figure 1 illustrates our theoretical framework.

\section{Hypotheses}

For a firm to innovate in whatever guise, it needs the motivation and ability to do so (Chandy et al., 2003; Debruyne et al., 2010; Hughes et al., 2021). EO creates a bias for action that motivates firms to persistently seek out market-based entrepreneurial opportunities for change (Wales et al., 2015, 2020). Entrepreneurially oriented firms seek to be the first to introduce products, innovations and technologies by capitalising on opportunities ahead of competitors (Ireland et al., 2003; Miller, 1983), and seek to shape markets (DiVito and Bohnsack, 2017). Taken together, these qualities ought to fuel explorative and exploitative product innovation search to enact the opportunities 
found by the incubating technology-based firm through its EO. Ultimately, EO embodies a managerial desire to unsettle and change the nature of competition, which manifests itself in either disturbing existing product-market conditions or spearheading the development of new market space, or both exploit and explore (Ireland et al., 2003; Kollmann and Stöckmann, 2014; Ramachandran et al., 2019; Zhang et al., 2016).

EO can, therefore, stimulate an internal environment sympathetic to breakthrough explorative innovation and provides conditions to support exploitative product innovation initiatives. The coming together of risk-taking, innovativeness and proactiveness moulds a supportive infrastructure to underpin the ideation, experimentation and creativity that both innovations rely on (Ireland and Webb, 2007; Lumpkin and Dess, 1996). EO should then set in place an organisational environment and framework conducive for explorative and exploitative innovations and their commercialisation. For example, EO should increase the identification of a rich stream of opportunities capable of unsettling the short-to-medium term movements of competitors (Covin and Wales, 2019). The innovativeness and proactiveness dimensions of EO push firms to exploit opportunities to manipulate the current and anticipated weaknesses of competitors with incrementally revised products, while the risk-taking dimension also prompts the firm to set more ambitious goals to commit resources to define new segments and develop new product offerings in the face of possible costly failure (Covin and Slevin, 1989; Hughes et al., 2018; Lumpkin and Dess, 1996). The effect is near-constant outmanoeuvring of rivals. The aggressive nature of EO traps less-inclined competitors in a suboptimal competitive situation in which rival firms imitate to defend market share against the entrepreneurial firm's innovating behaviour.

The effects of EO on product innovation can then be multiplicative as well. As a young entrepreneurially oriented firm innovates and proactively enters markets, the accompanying competitor reactions and reprisals prompt the firm to make further strategic adjustments to product-services and technologies (Anderson et al., 2009). Moreover, young and small firms with high risk-taking attitudes tend to engage in aggressive investment on current competitive advantages to refine competence of existing products (Covin and Wales, 2019; Lechner and Gudmundsson, 2014). Thus, the entrepreneurially oriented firm is sensitive not only to explorative innovations but also to the need to adapt new and existing products with further exploitative innovations. Therefore, we hypothesise the following:

\section{Hypothesis 1. Entrepreneurial orientation is positively related to explorative innovation.}

Hypothesis 2. Entrepreneurial orientation is positively related to exploitative innovation.

The availability and access to a stock of resources codetermine the incubating firm's ability to innovate. However, resource deficiencies are inherent problems in any innovation initiative and exacerbated for young technology-based firms. In response, managers can make strategic choices concerning relationships to alter the system of constraints affecting the firm's innovation activities (Pfeffer and Salancik, 1978). Ability of the managers to acquire and attract relational resources, thus, provides the ability to innovate by acquiring resources needed to fuel innovation activity (Ketchen et al., 2007).

Due to constraints of newness, intense competitive pressures mean that the time needed for incubating technology-based firms to develop resources internally to innovate new products and technologies is neither feasible nor appropriate. Using relational ties to locate and bring in external resources can expand the pool from which the incubating technology-based firm can perform innovation activity. A larger network can accelerate innovation (Ketchen et al., 2007). Resources brought into through external relationships with other firms made available through the incubator's 
network enables the incubating technology-based firm to experiment with new resource combinations while learning to refine existing ones (Ireland et al., 2003; Sirmon et al., 2007). Explorative and exploitative innovations should then emerge as the firm's motivation to challenge its market competitors is matched with the ability to build new and better products (Ireland and Webb, 2007). However, the simplicity of this argument masks a complex problem: explorative and exploitative innovation activities compete for scarce resources and the introduction of new (external) resources channels the attention of managers towards a different innovation activity. Voss et al. (2008) evidence this very concern. These authors found that absorbed, generic internal resources (consistent with the in-house competences of the incubating technology-based firm being tied to its first set of revenue-generating products) increased exploitative innovation and decreased explorative innovation because these resources are tied-up in present product-market offerings. The introduction of unabsorbed, new resources, however, changed firm behaviour towards higher levels of exploration and lower levels of exploitation for young and small firms.

In young technology-based firms then, a lack of internal resource slack means that most internal resources will be devoted to servicing current products. If external resources are brought in to encourage explorative activities, this will draw on scarce internal resources, which is inevitable given that (1) to access relational resources a firm must reciprocate in some form and (2) to explore new ways forward the firm must connect relational resources with its in-house resources, capabilities and expertise. Exploitative innovation activities will then be undermined as internal resources are drawn to fuel explorative endeavour, indicative of the exploitation/exploration trade-off. Voss et al. (2008) empirically demonstrate this trade-off in their study of small creative firms. Their discussion of the dilemma of [un]absorbed-[non-]generic resources for innovation activity of small firms reveals that unabsorbed non-generic resources lead to higher exploration and lower exploitation, whereas absorbed generic resources encourage more exploitative innovation activity. When internal resources are directed towards exploration, they are pulled from exploitation activities (March, 1991). External resources cannot plug this gap because such resources are new to the firm and direct attention towards exploration (Voss et al., 2008) without correcting for the loss of internal resources redirected from current product-market activities. This problem is consistent with theory on strategic entrepreneurship in which explorative innovation benefits from diversity but exploitative innovation benefits from focus (Ireland and Webb, 2007).

Reconfiguring the resources available to the young technology-based firm internally with those from its network provides the means to generate new, explorative product innovations to new and existing customers (Sirmon et al., 2007), but diverts resources away from the current, exploitative activities of the firm (Voss et al., 2008). We predict this will weaken exploitative innovation activity. To compound the problem, accessing relational resources requires a firm to reciprocate with its own. External resources are unlikely to plug the gaps that will emerge in the resourcing of the firm's pre-existing activities because relational resources are typically novel to the firm. A firm with internal resource slack would not face this problem, but such a scenario is far removed from the context of incubating technology-based firms.

Accessing relational resources strategically should increase the resources available for exploration activities in these firms, where little internal slack is typically present, but we would expect to see a commensurate reduction in resources for exploitation activities particularly as existing resources and capabilities are redirected to shape new products and technologies forming explorative innovations. Thus, we hypothesise the following:

Hypothesis 3. Acquiring and accessing relational resources is positively related to explorative innovation. 
Hypothesis 4. Acquiring and accessing relational resources is negatively related to exploitative innovation.

Relational ties can also help a young technology-based firm to plug knowledge gaps, and by crossing external boundaries, networking may enhance the young venture's capacity to acquire, develop and leverage knowledge that are owned and controlled by outside actors (El-Awad et al., 2017). Superficially, this may increase the potential for novel (re)combinations of knowledge and resources. However, as relational embeddedness increases, knowledge transfer becomes more redundant as ties become stronger and the novelty of that knowledge is reduced (Burt, 1992; Granovetter, 1973). Under this condition, we expect that while increased knowledge enables the incubating technology-based firm to learn to do better with the resources it has, improving exploitative innovation, increases in knowledge redundancy and a lack of novelty detract from its ability to invest in explorative innovation. This position is supported by the work of Dittrich and Duysters (2007) on the role of networks in innovation management.

Dittrich and Duysters (2007) argue that exploitative innovation benefits from maximising the number of strong ties with similar firms to strengthen and broaden the basic knowledge available to it. Young firms tend to form networks based on cohesive, social contacts (Hite and Hesterly, 2001) and so we would expect that greater amounts of relational embeddedness with firms similar to the young firm itself will provide it with opportunities to maintain longer term relationships in which the intensity and reciprocity of those relationships are high (Granovetter, 1973). The depth of knowledge sharing that should then occur ought to improve exploitative innovation (Dittrich and Duysters, 2007).

Over time, however, knowledge redundancy will occur as the amount of novel information the firm is exposed to will decrease rapidly (Burt, 1992; Granovetter, 1973). New ideas and novel knowledge are more likely to be found in weak ties or in sparse networks in which relational embeddedness is low. Dittrich and Duysters (2007) posit that firms pursuing explorative innovation will, therefore, need a breadth of relationships with partners they infrequently encounter by way of weak ties (i.e. lower relational embeddedness). These ties allow firms to bridge to disparate and novel pockets of new knowledge over time, thereby benefitting from the breadth of resources in the network (consistent with Hypothesis 3) while not suffering the redundancy effects that occur with higher levels of relational embeddedness (Burt, 1992; Granovetter, 1973). Therefore, we hypothesise the following:

Hypothesis 5. Relational embeddedness is negatively related to explorative innovation.

Hypothesis 6. Relational embeddedness is positively related to exploitative innovation.

Those incubating technology-based firms successful at achieving both innovation activities to a high standard and at striking an appropriate balance between the two can potentially achieve a competitive advantage that augments profitability. Emerging empirical evidence generally supports this view but reports of its effects are mixed (O'Reilly and Tushman, 2013) and point to the significance of context in the relationship between innovation ambidexterity and business performance (Luger et al., 2018). Studies have drawn attention to its sensitivity to the type of firm (Cao et al., 2009; Junni et al., 2013, 2020) and particularly to firm age and size (Chang and Hughes, 2012; Lubatkin et al., 2006; Mathias et al., 2018; Voss et al., 2008; Voss and Voss, 2013). For example, studies of innovation ambidexterity among small and medium-sized enterprises (SMEs) have reported positive performance returns (Chang et al., 2011; Colclough et al., 2019; Lubatkin et al., 2006) and equivalent returns to both innovation strategies separately (Morgan and Berthon, 2008). Ambidexterity can set the conditions for firms to profit from new market opportunities and current 
market opportunities. However, innovation ambidexterity risks over-stretching the young firm (Cao et al., 2009) and their naivety at managing the tensions in ambidexterity may lead it to be unproductive (Schad et al., 2016; Voss et al., 2008; Voss and Voss, 2013). Innovation ambidexterity is resource-intensive and requires managers to make active investment decisions that maintain a delicate balance between explorative and exploitative innovation activities (Fourné et al., 2019). Nonetheless, the lure for young technology-based firms successful at achieving innovation ambidexterity is the ability to secure the benefits of exploration while suffering fewer of its costs, establishing a platform for longer term sustainability, which could not accrue with a focus on exploitation alone (March, 1991). Thus, we expect the following hypothesis:

Hypothesis 7. Innovation ambidexterity is positively related to profitability.

\section{Methods}

\section{Sample}

We generated data from incubating, young technology-based firms. Such firms have reasons to be engaged in innovation and strategic entrepreneurship, and the context is advantageous because incubators offer immediate opportunities for young firms to start networking, offering opportunities to access relational resources and develop relational embeddedness with like firms. This sample was built using the United Kingdom Business Incubation (UKBI) directory of incubator facilities and cross-referenced with Internet and archival searches. We also inspected the United Kingdom Science Park Association directory to identify further incubator facilities. We identified 196 incubator facilities in total. We then screened each incubator to ensure our sample captured only young and new technology-based firms. Of the 196 incubators, 53 'general' incubators of no technological description were identified and were excluded from the sample to prevent sampling error. A list of the young technology-based firms within each of the 143 remaining incubators was then developed. We then randomly sampled until we had 1000 incubating young technology-based firms. These firms were double-checked for consistency with our requirements to prevent sampling error.

\section{Data collection}

Through preliminary interviews, we identified the lead entrepreneur in each firm as the most relevant informant (Hmieleski and Baron, 2008), defined as the founder or top management team leader (Chief Executive Officer or Managing Director; De Mol et al., 2018; Mueller et al., 2017). We then implemented a mail survey to generate data from these respondents. We pre-tested the survey instrument with academic researchers with expertise in strategic entrepreneurship and innovation to verify the content validity of the survey items. We then revisited our preliminary interview respondents (five lead entrepreneurs/managers and two incubator facility managers) to check the face validity of our items. Minor amendments were made to the survey. To increase the potential response rate, we reduced questionnaire length as far as possible, highlighted the relevance of the research in pre-notification and survey implementation phases, included a paid return postage envelope, included university sponsorship and UKBI endorsement, offered a report as an incentive and provided guarantees of anonymity and confidentiality. Pre-notification, a survey and information pack and two follow-up reminders were mailed to the firms in our sample.

We obtained 211 responses after removing a handful for being incomplete. We tested for nonresponse bias using the extrapolation method and found no statistically significant variable 
differences at conventional levels between early and late respondents. To assess informant validity, we asked respondents about their knowledge regarding the questions asked in the survey - anchored $1=$ no knowledge to $7=$ full knowledge $($ mean $=6.23, S D=0.92)-$ and the perceived accuracy of their responses about the 'realities' of their business - anchored $1=$ not at all accurate to $7=$ very accurate (mean $=6.03 ; S D=0.97$ ). These scores support informant validity. Respondents had an average of 21 years $(S D=10.55)$ industry experience, further indicating informant validity.

\section{Measures}

Measures were sourced from previous studies with small modifications made to the phrasing of some items to account for context. We performed qualitative interviews with entrepreneurs and managers of incubating firms and managers of incubator facilities before developing the survey and list of measures to ensure we understood the context. This informed our item selection process. These same interviewees were later re-interviewed to pilot test the measures. Table 1 contains the scales used in this study. Items were anchored with a 7-point response scale ranging from $1=$ strongly disagree to $7=$ strongly agree .

For entrepreneurial orientation representing opportunity-seeking behaviour, items for risk-taking, innovativeness and proactiveness were sourced from Covin and Slevin (1989).

For advantage-seeking behaviour, ${ }^{2}$ first, to measure accessing and acquiring relational resources, items were used that captured the extent to which a firm had accessed the inputs of other firms in the incubator network to address their resource deficiencies. These items were sourced from Sarkar et al. (2001). Sarkar et al.'s items for resource complementarity among networked firms and reciprocal commitment scales to ensure partners were making valuable resources available to each other were used to form a battery of scales to measure incubating technology-based behaviour of firms towards accessing relational resources. Second, relational embeddedness was operationalised using the items of Andersson et al. (2002). Minor adaptations were made to preexisting items to account for the context of incubating technology-based firms, which is recommended as good practice (Heggestad et al., 2019).

Measures for explorative innovation and exploitative innovation mirror Jansen et al.'s (2006) items and were sourced from Rindfleisch and Moorman (2001), Song and Parry (1997) and Song et al. (1998). ${ }^{3}$

We operationalised profitability as the one-year lagged net profit of the firm, a measure relevant to the performance of both product innovation activities treated in this study (Griffin and Page, 1996). These data were sourced from the 'Total Exemption Small' abbreviated accounts of the firms in our sample. ${ }^{4}$

Several control variables were specified. For explorative and exploitative innovations, we controlled for incubator size as larger incubators may facilitate (more) access to (more) resources, knowledge and opportunities. This control variable is reflected in the natural logarithm of the number of firms in each incubator. Following this logic further, we control for incubator facility type (ranked) as the type of incubator may present additional access to resources, knowledge and opportunities. Incubators are not homogeneous across the network opportunities they offer (changing the potential pool of resource and knowledge accessible to a young technology-based firm). Using our population data, we identified the type of centre/park/incubator respondent firms were located in. This variable is scaled with increased values reflecting increased complexity in the incubator. The scale was anchored as managed workspace (1; low); enterprise centre (2); innovation centre, technology centre and 'other' (3; midpoint types); business incubator (4); and science park (5; high). For profitability, firm age (natural logarithm) was used as a control variable as it is associated with greater time to accumulate resource stocks inside a firm and may then influence 
Table I. Measurement item properties.

Construct and measurement item

Standardised $t$-value

factor loading

Proactiveness

We excel at identifying opportunities $\quad .75$

11.07

We always try to take the initiative in every situation (e.g. against competitors, in $\quad .72$

projects and when working with others)

We initiate actions to which other organisations respond

.70

10.22

Risk-taking

People in our business are encouraged to take calculated risks with new ideas $\quad .60$

Our business frequently tries out new ideas

13.33

The term 'risk taker' is considered a positive attribute for people in our business .50

Our business seeks out new ways to do things

Innovativeness

Our business is creative in its methods of operation

Our business is often the first to market with new products and services

10.57

We actively introduce improvements and innovations in our business

13.28

Exploitative innovation

We drive improvements and revisions to existing products

We drive improvements in the ways in which we conduct our business

The overall quality of our products and services are higher than those of our competitors

Adapt your business adequately to changes in the business environment

Explorative innovation

We develop product technology new to the business

Our products rely on technology never before used in the industry

We have introduced products that are among the first of their kind in the market

We are responsible for 'new-to-the-world' innovations

We are responsible for new to the market/industry innovations

Accessing relational resources

Inputs brought into the centre/park by each participant are valuable for each other

Participants provide vital inputs we find difficult to obtain elsewhere

Participants share a level of mutual dependence to achieve stronger competitive

Operating in the centre/park allows our business to access a pool of inputs

Relational embeddedness

Relationships with centre/park businesses are important to our ability to

Relationships with centre/park businesses have led to changes in how we

Our relationships with centre/park businesses are important to our business activities 
performance. We controlled for industry type onto profitability also. Respondents self-identified their industry. Following Paytas and Berglund (2004), we sorted respondent firms into standard industry classifications and then, following the guidance and categorisation of Paytas and Berglund (2004), proceeded to classify all respondents into two industry types: secondary technology generators (scored as 1) and primary technology generators (scored as 2). The former classification of technology-based firms reflects relatively less technological intensity, while the latter reflects relatively high technological intensity. Primary technology generators exhibit proportionally higher numbers of full-time-equivalent R\&D staff and engineers and greater R\&D spend than those firms located in secondary technology generator industries (Paytas and Berglund, 2004). Firm size was controlled for in the sampling process.

\section{Common method variance}

We followed protocols (Podsakoff et al., 2012) for limiting common method variance (CMV) by placing items in random order in the survey, not implying any 'ideal' responses, employing impartial and neutral wording throughout, limiting the length of the questionnaire, and providing detailed instructions for its completion.

We performed two tests for CMV. First, we carried out a Harman one-factor test using confirmatory factor analysis (CFA) (Podsakoff et al., 2003). We placed all variables into a single CFA and examined the fit indices to determine whether a single latent factor would fit the data well. The results reveal that a single factor does not fit the data: $\chi^{2}=5725.48, d f=377, p<.01$, root mean square error of approximation $(\mathrm{RMSEA})=.26$, non-normed fit index $(\mathrm{NNFI})=.62$, comparative fit index $(\mathrm{CFI})=.65$, incremental fit index $(\mathrm{IFI})=.65$, standardised root mean square residual $(\mathrm{SRMR})=.23$. The $\chi^{2} / d f$ ratio far exceeds the $\leqslant 2.00$ cut-off (Bollen, 1989) and the RMSEA is unacceptably high (Hu and Bentler, 1999). The model fit statistics of NNFI, CFI, IFI and SRMR also reject a single-factor solution (Hu and Bentler, 1999).

Second, we performed a marker variable test (Lindell and Whitney, 2001). We selected 'respondent years of working experience' as a marker variable that is not theoretically related to all other measures in the study. Non-significant correlations $(p>.05)$ were found between the marker variable and all study variables. Next, we evaluated how much of the covariance between variables were affected by the common method, given that CMV affects the degree of variance between constructs. We assessed this by calculating a summation of the covariance difference between the marker variable and all study variables divided by the number of variables. Using this average marker variance $\left(r_{\mathrm{m}}=.27\right)$, we specified a CMV-adjusted covariance matrix between all the measures in the study. This adjusted covariance matrix was then used to re-specify the original measurement model. Changes in the measurement model in using the CMV-adjusted covariance were non-significant. The substitution did not significantly deteriorate model fit $\left(\Delta \chi^{2}=47.86 ; \Delta d f=0\right.$; $\Delta \mathrm{CFI}, \Delta \mathrm{NNFI}$ and $\triangle \mathrm{IFI}=.03 ; \Delta \mathrm{SRMR}=.01$ ). No material differences were found between any of the factor loadings in the modified CFA as compared to the original CFA. Consequently, these results imply that CMV does not threaten our data or results. We used the original measurement model for all subsequent analyses.

\section{Reliability and validity}

We examined all scales using exploratory factor analysis before CFA. Using LISREL 8.8, maximum likelihood estimation and the covariance matrix, we estimated our measurement model (Table 1). This measurement model $\left(\chi^{2}=674.92, d f=356, p<.01\right)$ resulted in excellent fit to the data $(\mathrm{CFI}=.96$; $\mathrm{IFI}=.96 ; \mathrm{NNFI}=.95 ; \mathrm{RMSEA}=.07 ; \mathrm{SRMR}=.06)$. Each item loaded significantly $(p<.01)$ onto the 
specified construct (ranging from .50 to .93). All construct reliabilities (CRs) exceed the recommended minimum threshold. Apart from one instance, average variance extracted (AVE) ranged from .51 to .79 , satisfying the $50 \%$ cut-off for convergent validity (Fornell and Larker, 1981). The exception is 'Exploitative Innovation' whose AVE was below .5. However, its CR is sufficiently above recommended thresholds (.67) and its inclusion is consistent with prior works in strategic entrepreneurship and strategic management. Furthermore, the square root of the AVE for each construct is greater than the off-diagonal coefficients, indicating discriminant validity among our constructs. This result gives confidence in the robustness of the data and respective constructs. Table 2 presents the descriptive statistics, correlations and robustness of each construct.

\section{Results}

Two structural equation models (SEM) were specified to satisfy acceptable parameter-to-observation ratios. SEM Model 1 examines the hypotheses associated with explorative and exploitative innovations. SEM Model 2 examines the profitability effects of both innovation activities and innovation ambidexterity. Both models demonstrate excellent model fit statistics (Table 2). For SEM Model 1, we created a higher order latent variable of 'Entrepreneurial Orientation' by summing together and averaging its three specified components (risk-taking, innovativeness and proactiveness). For SEM Model 2, we calculated an index of Innovation Ambidexterity. Existing calculations of innovation ambidexterity speak separately to the relative magnitude of ambidexterity (Cao et al., 2009; Chen et al., 2021; Jansen et al., 2012; Koryak et al., 2018; Posch and Garaus, 2020) (a 'combined dimension', calculated through addition or multiplication) and the relative balance of exploration and exploitation (Cao et al., 2009; Chang et al., 2011; He and Wong, 2004) (a 'balance dimension', calculated through subtraction). We use both in our calculation, generating an index of the magnitude of innovation ambidexterity and the balance of ambidexterity exhibited by the firm.

Three salient matters drove our reasoning. First, Hughes (2018) notes that the subtractive approach captures the extent to which the exploration and exploitation are balanced, but the multiplicative approach captures the quality of both activities that make up that balance. But a firm may have perfect balance but be mediocre at both exploration and exploitation. As Simsek (2009) noted, 'an organisation with low levels of exploitation and exploration is 'balanced', but not ambidextrous' (p. 603). Second, subtraction creates a positive or negative score, yet, whether one arrives at a positive or a negative polarity is dictated by whether exploration or exploitation enters the equation first. The sign is then potentially erroneous, providing false values when what matters is determining deviance (imbalance) (Hughes, 2018). Third, the additive or multiplicative approach is also potentially flawed because it fails to account for balance. Simply adding or multiplying values of exploration and exploitation neglects that any difference between the two causes relevant implications that are missed in such a calculation. Information relevant to the actual ambidexterity of a firm is then lost (Hughes, 2018).

Following this discussion, we concluded that an accurate calculation of innovation ambidexterity must account for both balance and magnitude but must also correct the flaw in the balance calculation. Thus

\section{Innovation Ambidexterity = Ambidexterity Quality - Imbalance}

First, we calculate imbalance by adjusting the formula to square and then square root the absolute difference between exploration and exploitation to obtain a pure difference score (negating the false polarity caused by entering either exploration or exploitation into the equation first) 
Table 2. Descriptive statistics, construct robustness and model fit.

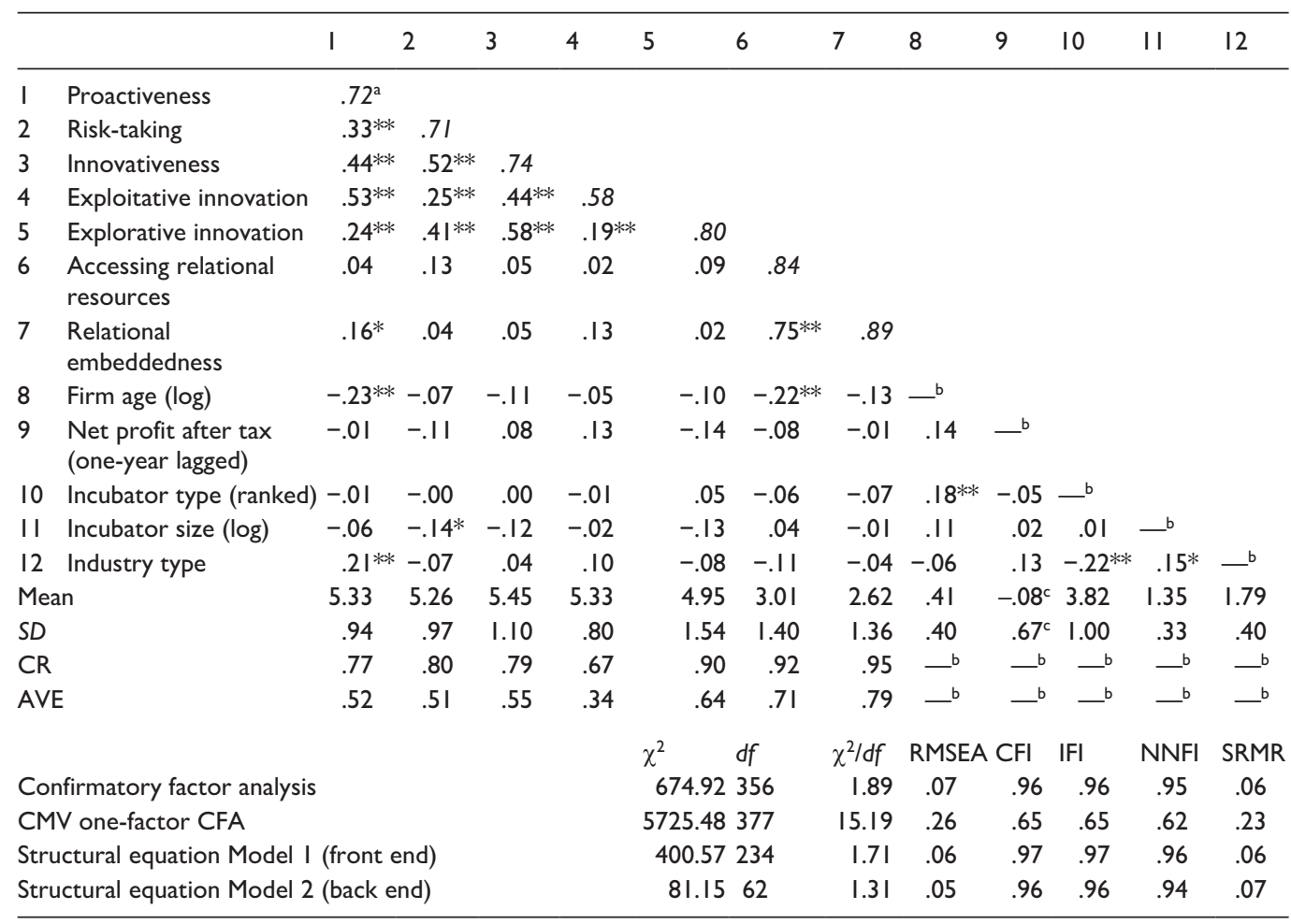

SD: standard deviation; CR: construct reliability; AVE: average variance extracted; RMSEA: root mean square error of approximation; CFI: comparative fit index; IFI: incremental fit index; NNFI: non-normed fit index; SRMR: standardised root mean square residual; CMV: common method variance; CFA: confirmatory factor analysis.

aFigures on the diagonal are the square root of the AVE of each construct.

bNot applicable. Single-item constructs; cannot be computed.

${ }^{\mathrm{C}} \mathrm{GBP}$ millions.

**Significant at $1 \%$ level.

*Significant at $5 \%$ level.

$$
\text { Innovation Ambidexterity Imbalance }=\sqrt{(\text { Explore }- \text { Exploit })^{2}}
$$

Second, the magnitude, or quality, of ambidexterity is calculated by multiplying together the scores for exploration and exploitation activities (a multiplicative score is generally preferred to addition as it provides more information on the differences between exploration and exploitation)

\section{Innovation Ambidexterity Quality $=$ Explore $\times$ Exploit}

The final mathematical calculation for Innovation Ambidexterity is

$$
\text { Innovation Ambidexterity }=\sum\left((\text { Explore } \times \text { Exploit })-\sqrt{(\text { Explore }- \text { Exploit })^{2}}\right)
$$


Table 3. Results.

\begin{tabular}{|c|c|c|c|c|c|c|}
\hline & \multicolumn{6}{|c|}{ Dependent variable } \\
\hline & \multicolumn{2}{|l|}{$\begin{array}{l}\text { Exploitative } \\
\text { innovation }\end{array}$} & \multicolumn{2}{|l|}{$\begin{array}{l}\text { Explorative } \\
\text { innovation }\end{array}$} & \multicolumn{2}{|c|}{$\begin{array}{l}\text { Profitability (Net Profit } \\
\text { (one-year lagged)) }\end{array}$} \\
\hline & $\begin{array}{l}\text { Standardised } \\
\text { Path } \\
\text { Coefficient }\end{array}$ & $t$-value & $\begin{array}{l}\text { Standardised } \\
\text { Path } \\
\text { Coefficient }\end{array}$ & $t$-value & $\begin{array}{l}\text { Standardised } \\
\text { Path } \\
\text { Coefficient }\end{array}$ & $t$-value \\
\hline \multicolumn{7}{|l|}{ Direct effects } \\
\hline Entrepreneurial orientation & .60 & $5.32 * *$ & .69 & $7.35 * *$ & & \\
\hline Accessing relational resources & -.33 & $-2.22^{*}$ & .15 & $1.32^{\dagger}$ & & \\
\hline Relational embeddedness & .37 & $2.5 I^{* *}$ & -.16 & $-1.40^{\dagger}$ & & \\
\hline Exploitative Innovation & & & & & .24 & $2.11 *$ \\
\hline Explorative innovation & & & & & -.58 & $-2.56^{* *}$ \\
\hline Innovation ambidexterity & & & & & .42 & $1.76 *$ \\
\hline \multicolumn{7}{|l|}{ Control variables } \\
\hline Incubator type & .02 & .18 & .08 & I.II & & \\
\hline Incubator size & -.14 & -.56 & .16 & 0.76 & & \\
\hline Firm age & & & & & .03 & .11 \\
\hline Industry type & & & & & -.12 & -.90 \\
\hline $\begin{array}{l}\text { Variance explained in the } \\
\text { dependent variable }\end{array}$ & .41 & & .48 & & .20 & \\
\hline
\end{tabular}

aSquared multiple correlations for reduced form.

Critical $t$-values (one-tailed as all hypotheses are directional): when $* * p=.0$ I, critical $t$-value $=2.326$; when $* p=.05$, critical $t$-value $=1.645 ;$ when ${ }^{\dagger} p=.10$, critical $t$-value $=1.282$.

This formula provides a score of innovation ambidexterity quality that is adjusted by the degree of imbalance present in the firm. Where firms exhibit high exploitation and exploration, there is little or no imbalance and so the value of ambidexterity remains high. Where respondents favour one specific activity over another, the value of ambidexterity is adjusted to correct for this imbalance. This calculation addresses Simsek's (2009) concern that scholars 'consider very carefully their choice of measurement system when performing any empirical analysis of organisational ambidexterity, and particularly when examining its effects on firm performance' (p. 603).

Hypothesis testing results are presented in Table 3. The independent variables explain $48 \%$ of the variance in explorative innovation. EO positively affects explorative innovation (H1) $(t=7.35$; $p \leqslant .01)$; accessing and acquiring relational resources (H3) also positively affects explorative innovation $(t=1.32 ; p \leqslant .10)$; and $\mathrm{H} 5$ is supported as relational embeddedness is negatively related to explorative innovation activity $(t=-1.40 ; p \leqslant .10)$. Meanwhile, the structural model explains $41 \%$ of the variance in exploitative innovation. As hypothesised, EO (H2; $t=5.32 ; p \leqslant .01)$ and relational embeddedness $(\mathrm{H} 6 ; t=2.51 ; p \leqslant .01)$ positively affect exploitative innovation and accessing and acquiring relational resources (H4) negatively affects exploitative innovation activity $(t=-2.22$; $p \leqslant .05)$. Innovation ambidexterity $(\mathrm{H} 7)$ has a positive relationship with profitability $(t=1.76$; $p \leqslant .05)$ as predicted. For added nuance, we included in our statistical model paths for the effects of exploitative innovation $(t=2.11 ; p \leqslant .05)$ and explorative innovation $(t=-2.56 ; p \leqslant .01)$ on oneyear lagged net profit. Taken together, $20 \%$ of the variance in net profit is explained. Ambidexterity rewards the profitability of young technology-based firms by combining innovation strategies, which in this case may offset some of the costs associated with explorative innovation alone. 


\section{Discussion}

Innovation ambidexterity is particularly important for young technology-based firms to overcome the liabilities of newness by implementing exploitative innovation which improve technology portfolio management, advance production procedure and attain know-how on specific technological area (Choi and Shepherd, 2005; Kollmann and Stöckmann, 2014). Simultaneously, these firms attain the ability to maintain the assets of newness such as organisational flexibility (Choi and Shepherd, 2005) and remain ahead of pressures from technology shifts and shortened product lifecycles by conducting explorative innovation. Therefore, young technology-based firms need to understand the value of both explorative and exploitative innovations to surmount obstacles and achieve high firm profitability. Our study provides novel theorising and empirical evidence of the principles of strategic entrepreneurship as it applies to explorative and exploitative innovation activity and innovation ambidexterity for young technology-based firms in incubators.

The results identify opportunity-seeking behaviour in the form of EO as a key factor in motivating exploitative innovation and explorative innovation. This suggests that EO as the opportunity-seeking component of strategic entrepreneurship is essential for incubating technology-based firms to obtain the profitability benefits that accrue from innovation ambidexterity. EO, therefore, provides the organising principle to ensure that firms focus their behaviours on repeating and improving the conditions responsible from present success (exploitative innovation) and to create the required variety for future viability (explorative innovation). Given the tensions inherent in the ambidexterity thesis (Junni et al., 2015; March, 1991; Tushman and O'Reilly, 1996; Zimmermann et al., 2018), EO is a means by which to manage the interfaces between exploration and exploitation.

The situation for advantage-seeking behaviours - relational embeddedness and relational resources - is far less clear-cut. We find that relational embeddedness is an essential contributor to successful instances of exploitative innovation. However, relying on locating and accessing relational resources affects negatively on instances of exploitative innovation, which may occur as a result of internal resources being re-bundled with externally sourced resources in pursuit of explorative innovation (Voss et al., 2008). Scholars recognise that the resources and capabilities for exploration (or exploitation) increasing lie beyond the boundaries of the firm and rely on networks of relationships (Stadler et al., 2014; Wilden et al., 2018). This is certainly the case for resourcedeficient young technology-based firms.

These findings highlight a lapse in current treatments of relational resources and relational embeddedness in ambidexterity research (Feng et al., 2019; Heavey et al., 2015), which have failed to anticipate negative consequences for ambidexterity at the disaggregated level. This is in part driven by the failure of studies to account for context (Khan et al., 2018; Zahra et al., 2014). We concur with Dittrich and Duysters (2007) that the type of network ties formed by managers has a bearing on firm innovation outcomes but expand on their work by revealing that stronger ties exhibited by greater degrees of relational embeddedness benefit exploitative innovation, but at a cost to explorative innovation, and vice versa for the role of access to relational resources for innovation activities. These differing findings are symptomatic of the lack of treatment of the antecedents and consequences of explorative and exploitative innovation activities in young firms.

This discussion crystallises our first and second contributions to reshaping and re-interpreting the thinking of researchers around strategic entrepreneurship and innovation ambidexterity for young technology-based firms. First, we establish a theoretical argument that uncovers the strategic entrepreneurship conditions that promote explorative and exploitative innovation activities, as called for by Anderson et al. (2019) and Junni et al. (2015). In doing so, this article provides a first theoretical rationale that aligns the opposing dimensions of strategic entrepreneurship - being 
opportunity-seeking and advantage-seeking - and innovation theory to explain emergence of explorative and exploitative innovations in the context of young technology-based firms in incubators. This has important implications for investigations of the foundations of innovation ambidexterity by researchers. Specifically, it demonstrates how externally sourced resources and knowledge can supplement internal activities, but also actively change them as the young firm engages in resource reallocation and applies these external resources to different (competing) routines and activities. Whereas EO serves as a unifying mechanism for both types of innovation activities and underpins their ambidexterity. Second, in developing this theoretical logic, we also provide additional contextual nuance by positioning our theoretical narrative within incubating technologybased firms. Accordingly, we correct for the tendency to relegate context to a mere control variable in entrepreneurship (Zahra et al., 2014), EO (Yin et al., 2020) and ambidexterity studies (Khan et al., 2018; O'Reilly and Tushman, 2013; Stettner and Lavie, 2014). Collectively, these contributions provide novel theorising and empirical evidence of strategic entrepreneurship as it applies to innovation ambidexterity for incubating technology-based firms. Our theoretical logic and narrative set essential new building blocks for further scholarly research into the contextual antecedents of innovation ambidexterity, extending calls by Birkinshaw and Gupta (2013), Kassotaki et al. (2019) and O’Reilly and Tushman (2013), among others.

For our third contribution, we extend the literature on strategic entrepreneurship by advancing its conceptualisation. Specifically, we attempt to resolve the ambiguity that surrounds exactly what represents opportunity- and advantage-seeking behaviour as lamented by Simsek et al. (2017). For example, our theory and findings extend the understanding of scholars of the forms of advantageseeking behaviour needed to secure innovation outcomes among resource-challenged and knowledge-deficient incubating technology-based firms and help scholars understand the competing effects these have on the innovation process for incubating technology-based firms. Relational embeddedness and accessing relational resources, representing their advantage-seeking behaviour, exacerbate the tensions of innovation ambidexterity. Thus, drawing on both strategic entrepreneurship and innovation literature, we advance knowledge on the foundations of ambidexterity by unravelling how external collaborative efforts orchestrated by managers might alter the firm's landscape for innovation ambidexterity. Specifically, we reveal advantage-seeking behaviour to be a further important organising principle for innovation ambidexterity, one that bears a markedly different effect on explorative innovation versus exploitative innovation activity. However, this insight derives from conceptualising strategic entrepreneurship to the context of the subject of interest (in our case incubating technology-based firms). We expand the conceptual basis available for scholars to make predictions about the emergence of ambidexterity, especially in resourceconstrained, young technology-based firms, long called for among scholars (Cao et al., 2009; Chang and Hughes, 2012; Hughes, 2018). Consequently, we enrich scholarly knowledge about the conceptual origins of ambidexterity (Heavey and Simsek, 2017; Mom et al., 2015; Volery et al., 2015) from the perspective of strategic entrepreneurship.

\section{Managerial implications}

The findings offer a prescription for product innovation ambidexterity management in young firms, driven by the need for managers to implement an EO. Specifically, the improvement in opportunity-seeking behaviour through an EO increases the firm's capability at identifying opportunities to both exploit by improving present product-market offerings and to explore through generating truly new innovations. The added complexity for managers here is that the deployment of EO must occur in parallel with advantage-seeking behaviours to appreciate where problems in the management of innovation in a strategically entrepreneurial manner might originate from. 
In the pursuit of innovation ambidexterity, managers must consider and manage the resource trade-offs and tensions that exist (Zimmermann et al., 2018). Locating relational resources fuels efforts towards explorative innovation but that exploratory process can then pull resources and managerial attention away from exploitative innovation activities. Managers must evaluate internal resource slack or resource constraints despite sourcing resources externally and consider the impact such efforts can have on its profit-driving exploitative innovations. Put differently, sourcing resources externally is not a panacea to resource inadequacies that typically prevent, constrain or undermine broader innovation efforts by young firms. However, deploying strong ties over and above a sparse network of weak ties by increasing relational embeddedness can have the converse effect of improving exploitative innovation by reducing the knowledge deficiencies of the firm, but can trap it in a suboptimal state of increased knowledge redundancy.

Careful consideration must be given to exploitation and exploration relative to performance goals. Exploitation brings more immediate profit returns that risk being seen too favourably compared with the short-term losses that exploitation can entail. The negative association between exploration and one-year lagged profits indicates a longer time horizon is likely for returns to accrue. Managers of incubating firms, then, must caution against overreacting to this and abandon exploration in favour of the immediacy that exploitation brings for meeting profit goals.

\section{Limitations and future research}

Some limitations bear relevance on the study findings. First, future research should instead unpack the relationships among strategic entrepreneurship and innovation and further contemplate the strategic entrepreneurship-innovation problem given the network of effects reported in this study. For instance, a focus on exploitative innovation implies strong focus on current customers which may limit future growth through an EO and its more exploratory outcomes (Eggers et al., 2013). Second, our empirical context means that our results can only be generalised to incubating technology-based firms. Young technology-based firms in incubators may have self-selected into these contexts for some reason and would be expected to be more growth-oriented compared with the larger population of young technology-based firms. In general, there may be potential differences that bear implications for the ability to generalise our findings beyond the incubator context. More research is needed, therefore.

In young firms, the distance between the behaviours of managers and firm-level outcomes is very small, relative to larger organisations (Cole and Mehran, 2016), which allows for a more precise examination of the underlying processes by which ambidexterity emerges and evolves; as we document in our study. However, there is a danger in assuming that creating high levels of both exploration and exploitation is always beneficial for firms (Cao et al., 2009; March, 1991; cf. Simsek, 2009; Simsek et al., 2009), neglecting the value and purpose of each activity and their conceptual origins and status in such firms. Future research should focus on the context-sensitivity of the ambidexterity-performance relationship and its antecedents in view of theory, our conceptualisation and results.

\section{Conclusion}

We provide new knowledge on the origins of innovation ambidexterity for young, incubating technology-based firms. Strategic entrepreneurship behaviours enable explorative and exploitative innovations. However, we find competing interrelationships that both ease and exacerbate the tensions associated with innovation ambidexterity. These conflicts can be reconciled by managing the patterns of conditions to do with EO, accessing relational resources and relational embeddedness. 
We offer scholars a context-sensitive assessment of EO and innovation ambidexterity for young technology-based firms in incubators. We encourage further work on context, EO and innovation ambidexterity with a specific view towards unravelling when and through what means strategic entrepreneurship benefits young technology-based firms.

\section{Acknowledgements}

Earlier drafts were presented at Durham University, Newcastle University and Warwick University and at the Strategic Management Society Annual Conference. We are grateful to the participants for their valuable feedback. We also offer our sincere thanks to our anonymous reviewers for their constructive comments in the development of this manuscript.

\section{Funding}

The author(s) received no financial support for the research, authorship and/or publication of this article.

\section{ORCID iDs}

Mathew Hughes (iD https://orcid.org/0000-0001-6859-558X

Younggeun Lee (iD https://orcid.org/0000-0002-4723-2728

\section{Notes}

1. EO might include an element of advantage-seeking behaviour, and ambiguity remains as to what exactly represents opportunity - and/or advantage-seeking behaviour (Simsek et al., 2017). However, 'advantage-seeking behaviour is concerned with extending and deepening a firm's existing competitive advantage, whereas opportunity-seeking behaviour is concerned with recognizing and developing opportunities for new sources of competitive advantage' (Simsek et al., 2017: 506). Insofar as the fields of entrepreneurship and strategic management both have an interest in how firms create change by adapting or proacting to opportunities in their external environment (Ireland et al., 2003), the difference lies in the general tendency, emphasis or preponderance of a particular construct that has crossover into both fields. It is this general tendency and preponderance that we see as critical to determining why, as a component of strategic entrepreneurship, EO rests as a form of opportunity-seeking behaviour. As Simsek et al. (2017) discern, '[b]ecause corporate entrepreneurship and entrepreneurial orientation often exist outside a firm's competitive advantage, they do not necessarily always entail a strategic dimension' (p. 514). EO at the most fundamental level represents the manifestation of entrepreneurship as a firm attribute (Covin and Wales, 2019). We thank anonymous Reviewer 2 for encouraging this clarification.

2. An operationalisation of advantage-seeking behaviour as an aspect of strategic entrepreneurship must capture the efforts of the firm to establish advantage, not its efforts to apply advantage.

3. Item 4 for exploitative innovation (Table 1 ) was anchored $1=$ very poor to $7=$ excellent.

4. Under UK law, only registered, limited liability businesses must submit financial accounts to Her Majesty's Revenue and Customs and Companies House (the public repository). Even then, only public limited companies must make available these full accounts. For private limited companies that are classed as small, only Total Exemption Small accounts are required. These accounts are abbreviated and are not freely available. The firms in our sample were small and the majority were private-registered companies. We purchased the accounts $(n=152)$ from Companies House. Some were not registered, and no secondary data could be sourced for them.

\section{References}

Anderson BS, Covin JG and Slevin DP (2009) Understanding the relationship between entrepreneurial orientation and strategic learning capability: An empirical investigation. Strategic Entrepreneurship Journal 3(3): 218-240. 
Anderson BS, Eshima Y and Hornsby JS (2019) Strategic entrepreneurial behaviours: Construct and scale development. Strategic Entrepreneurship Journal 13(2): 199-220.

Andersson U, Forsgren M and Holm U (2002) The strategic impact of external networks: Subsidiary performance and competence development in the multinational corporation. Strategic Management Journal 23(11): 979-996.

Arunachalam S, Ramaswami SN, Herrmann P, et al. (2018) Innovation pathway to profitability: The role of entrepreneurial orientation and marketing capabilities. Journal of the Academy of Marketing Science 46(4): 744-766.

Arzubiaga U, Kotlar J, De Massis A, et al. (2018) Entrepreneurial orientation and innovation in family SMEs: Unveiling the (actual) impact of the Board of Directors. Journal of Business Venturing 33(4): 455-469.

Bank N, Fichter K and Klofsten M (2017) Sustainability-profiled incubators and securing the inflow of tenants: The case of Green Garage Berlin. Journal of Cleaner Production 157: 76-83.

Birkinshaw J and Gupta K (2013) Clarifying the distinctive contribution of ambidexterity to the field of organisation studies. Academy of Management Perspectives 27(4): 287-298.

Bollen KA (1989) Structural Equations with Latent Variables. New York: John Wiley \& Sons.

Burgess N, Strauss K, Currie G, et al. (2015) Organisational ambidexterity and the hybrid middle manager: The case of patient safety in UK hospitals. Human Resource Management 54(S1): 87-109.

Burt RS (1992) Structural Holes: The Social Structure of Competition. Cambridge, MA: Harvard University Press.

Cai L, Hughes M and Yin M (2014) Relationship between resource acquisition methods and firm performance in Chinese new ventures. Journal of Small Business Management 52(3): 365-389.

Cao Q, Gedajlovic E and Zhang H (2009) Unpacking organisational ambidexterity: Dimensions, contingencies, and synergistic effects. Organization Science 20(4): 781-796.

Chan KF and Lau T (2005) Assessing technology incubator programs in the science park: The good, the bad and the ugly. Technovation 25(10): 1215-1228.

Chandy RK, Prabhu JC and Antia KD (2003) What will the future bring? Dominance, technology expectations, and radical product innovation. Journal of Marketing 67(3): 1-19.

Chang Y-Y and Hughes M (2012) Drivers of innovation ambidexterity in small- to medium-sized firms. European Management Journal 30(1): 1-17.

Chang Y-Y, Hughes M and Hotho S (2011) Internal and external antecedents of SMEs' innovation ambidexterity outcomes. Management Decision 49(10): 1658-1676.

Chen J, Miller D and Chen M-J (2021) Top management team time horizon blending and organizational ambidexterity. Strategic Organization 19(2): 183-206.

Choi YR and Shepherd DA (2005) Stakeholder perceptions of age and other dimensions of newness. Journal of Management 31(4): 573-596.

Colclough SN, Moen Ø, Hovd NS, et al. (2019) SME innovation orientation: Evidence from Norwegian exporting SMEs. International Small Business Journal 37(8): 780-803.

Cole RA and Mehran H (2016) What do we know about executive compensation at small privately held firms? Small Business Economics 46(2): 215-237.

Covin JG and Slevin DP (1989) Strategic management in small firms in hostile and benign environments. Strategic Management Journal 10(1): 75-87.

Covin JG and Wales WJ (2019) Crafting high-impact entrepreneurial orientation research: Some suggested guidelines. Entrepreneurship Theory and Practice 43(1): 3-18.

De Mol E, Ho VT and Pollack JM (2018) Predicting entrepreneurial burnout in a moderated mediated model of job fit. Journal of Small Business Management 56(3): 392-411.

Debruyne M, Frambach RT and Moenaert R (2010) Using the weapons you have: The role of resources and competitor orientation as enablers and inhibitors of competitive reaction to new products. Journal of Product Innovation Management 27(2): 161-178.

Deligianni I, Voudouris I, Spanos Y, et al. (2019) Non-linear effects of technological competence on product innovation in new technology-based firms: Resource orchestration and the role of the entrepreneur's political competence and prior start-up experience. Technovation 88: 102076. 
Dittrich K and Duysters GM (2007) Networking as a means to strategy change: The case of open innovation in mobile telephony. Journal of Product Innovation Management 24(5): 510-521.

DiVito L and Bohnsack R (2017) Entrepreneurial orientation and its effect on sustainability decision tradeoffs: The case of sustainable fashion firms. Journal of Business Venturing 32(5): 569-587.

Durisin B and Todorova G (2012) A study of the performativity of the 'ambidextrous organisations' theory: Neither lost in nor lost before translation. Journal of Product Innovation Management 29(S1): 53-75.

Eggers F, Kraus S, Hughes M, et al. (2013) Implications of customer and entrepreneurial orientations for SME growth. Management Decision 51(3): 524-546.

El-Awad Z, Gabrielsseon J and Politis D (2017) Entrepreneurial learning and innovation: The critical role of team-level learning for the evolution of innovation capabilities in technology-based ventures. International Journal of Entrepreneurial Behavior \& Research 23(3): 381-405.

Feng Y, Teng D and Hao B (2019) Joint actions with large partners and small-firm ambidexterity in asymmetric alliances: The mediating role of relational identification. International Small Business Journal 37: 689-712.

Fornell C and Larker DF (1981) Evaluating structural equation models with unobservable variables and measurement error. Journal of Marketing Research 18(1): 39-50.

Fourné SP, Rosenbusch N, Heyden ML, et al. (2019) Structural and contextual approaches to ambidexterity: A meta-analysis of organisational and environmental contingencies. European Management Journal 37(5): 564-576.

Gibson CB and Birkinshaw J (2004) The antecedents, consequences and mediating role of organisational ambidexterity. Academy of Management Journal 47(2): 209-226.

Granovetter MS (1973) The strength of weak ties. American Journal of Sociology 78(6): 1360-1380.

Griffin A and Page AL (1996) PDMA success measurement project: Recommended measures for product development success and failure. Journal of Product Innovation Management 13(6): 478-496.

He Z-L and Wong P-K (2004) Exploration vs. exploitation: An empirical test of the ambidexterity hypothesis. Organization Science 15(4): 481-494.

Heavey C and Simsek Z (2017) Distributed cognition in top management teams and organisational ambidexterity: The influence of transactive memory systems. Journal of Management 43(3): 919-945.

Heavey C, Simsek Z and Fox BC (2015) Managerial social networks and ambidexterity of SMEs: The moderating role of a proactive commitment to innovation. Human Resource Management 54(S1): 201-221.

Heggestad ED, Scheaf DJ, Banks GC, et al. (2019) Scale adaptation in organisational science research: A review and best-practice recommendations. Journal of Management 45(6): 2596-2627.

Hite JE and Hesterly WS (2001) The evolution of firm networks: From emergence to early growth of the firm. Strategic Management Journal 22: 275-286.

Hitt MA, Ireland RD, Sirmon DG, et al. (2011) Strategic entrepreneurship: Creating value for individuals, organisations and society. Academy of Management Perspectives 25(2): 57-75.

Hmieleski KT and Baron RA (2008) Regulatory focus and new venture performance: A study of entrepreneurial opportunity exploitation under conditions of risk versus uncertainty. Strategic Entrepreneurship Journal 2(4): 285-299.

$\mathrm{Hu}$ L and Bentler PM (1999) Cutoff criteria for fit indices in covariance structure analysis: Conventional criteria versus new alternatives. Structural Equation Modeling 6(1): 1-55.

Hughes M (2018) Organisational ambidexterity and firm performance: Burning research questions for marketing scholars. Journal of Marketing Management 34(1-2): 178-229.

Hughes M and Morgan RE (2007) Deconstructing the relationship between entrepreneurial orientation and business performance at the embryonic stage of firm growth. Industrial Marketing Management 36(5): 651-661.

Hughes M, Chang Y-Y, Hodgkinson IR, et al. (2021) The multi-level effects of corporate entrepreneurial orientation on business unit radical innovation and financial performance. Long Range Planning 54(1): 101989. DOI: $10.1016 /$ j.lrp.2020.101989

Hughes M, Ireland RD and Morgan RE (2007) Stimulating dynamic value: Social capital and business incubation as a pathway to competitive success. Long Range Planning 40(2): 154-177. 
Hughes M, Martin SL, Morgan RE, et al. (2010) Realizing product-market advantage in high-technology international new ventures: The mediating role of ambidextrous innovation. Journal of International Marketing 18(4): 1-21.

Hughes M, Morgan RE, Ireland RD, et al. (2014) Social capital and learning advantages: A problem of absorptive capacity. Strategic Entrepreneurship Journal 8(3): 214-233.

Hughes P, Hodgkinson IR, Hughes M, et al. (2018) Explaining the entrepreneurial orientation-performance relationship: The intermediate roles of absorptive capacity and improvisation. Asia Pacific Journal of Management 35: 1025-1053.

Inkpen AC and Tsang EWK (2005) Social capital, networks, and knowledge transfer. Academy of Management Review 30(1): 146-165.

Ireland RD and Webb JW (2007) Strategic entrepreneurship: Creating competitive advantage through streams of innovation. Business Horizons 50(1): 49-59.

Ireland RD and Webb JW (2009) Crossing the great divide of strategic entrepreneurship: Transitioning between exploration and exploitation. Business Horizons 52(5): 469-479.

Ireland RD, Hitt MA and Sirmon DG (2003) A model of strategic entrepreneurship: The construct and its dimensions. Journal of Management 29(6): 963-989.

Jansen JJP, Simsek Z and Cao Q (2012) Ambidexterity and performance in multi-unit contexts: Cross-level moderating effects of structural and resource attributes. Strategic Management Journal 33(11): 12861303.

Jansen JJP, Van Den Bosch FAJ and Volberda HW (2006) Exploratory innovation, exploitative innovation, and performance: Effects of organisational antecedents and environmental moderators. Management Science 52(11): 1661-1674.

Junni P, Chang Y-Y and Sarala RM (2020) Ambidextrous orientation and performance in corporate venture units: A multilevel analysis of CV units in emerging market multinationals. Long Range Planning 53(6): 101930. DOI: 10.1016/j.lrp.2019.101930

Junni P, Sarala RM, Taras V, et al. (2013) Organisational ambidexterity and performance: A meta-analysis. Academy of Management Perspectives 27(4): 299-312.

Junni P, Sarala RM, Tarba SY, et al. (2015) Guest editors' introduction: The role of human resources and organisational factors in ambidexterity. Human Resource Management 54(S1): 1-28.

Kassotaki O, Paroutis S and Morrell K (2019) Ambidexterity penetration across multiple organisational levels in an aerospace and defense organization. Long Range Planning 52(3): 366-385.

Ketchen DJ, Ireland RD and Snow CC (2007) Strategic entrepreneurship, collaborative innovation, and wealth creation. Strategic Entrepreneurship Journal 1(3-4): 371-385.

Khan Z, Rao-Nicholson R and Tarba SY (2018) Global networks as a mode of balance for exploratory innovations in a late liberalizing economy. Journal of World Business 53(3): 392-402.

Kollmann T and Stöckmann C (2014) Filling the entrepreneurial orientation-performance gap: The mediating effects of exploratory and exploitative innovations. Entrepreneurship Theory and Practice 38(5): $1001-1026$.

Koryak O, Lockett A, Hayton J, et al. (2018) Disentangling the antecedents of ambidexterity: Exploration and exploitation. Research Policy 47(2): 413-427.

Kuratko DF and Audretsch DB (2013) Clarifying the domains of corporate entrepreneurship. International Entrepreneurship and Management Journal 9(3): 323-335.

Lasrado V, Sivo S, Ford C, et al. (2016) Do graduated university incubator firms benefit from their relationship with university incubators? Journal of Technology Transfer 41(2): 205-219.

Lechner C and Gudmundsson SV (2014) Entrepreneurial orientation, firm strategy and small firm performance. International Small Business Journal 32(1): 36-60.

Levinthal DA and March JG (1993) The myopia of learning. Strategic Management Journal 14(S2): 95-112. Lindell MK and Whitney DJ (2001) Accounting for common method variance in cross-sectional designs. Journal of Applied Psychology 86(1): 114-121.

Lubatkin MH, Simsek Z, Ling Y, et al. (2006) Ambidexterity and performance in small-to medium-sized firms: The pivotal role of top management team behavioural integration. Journal of Management 32(5): 646-672. 
Luger J, Raisch S and Schimmer M (2018) Dynamic balancing of exploration and exploitation: The contingent benefits of ambidexterity. Organization Science 29(3): 449-470.

Lumpkin GT and Dess GG (1996) Clarifying the entrepreneurial orientation construct and linking it to performance. Academy of Management Review 21(1): 135-172.

March JG (1991) Exploration and exploitation in organisational learning. Organization Science 2(1): 71-87.

Mathias BD, Mckenny AF and Crook TR (2018) Managing the tensions between exploration and exploitation: The role of time. Strategic Entrepreneurship Journal 12(3): 316-334.

Mazzei MJ (2018) Strategic entrepreneurship: Content, process, context, and outcomes. International Entrepreneurship and Management Journal 14(3): 657-670.

Mazzei MJ, Ketchen DJ, Jr and Shook CL (2017) Understanding strategic entrepreneurship: A 'theoretical toolbox' approach. International Entrepreneurship and Management Journal 13: 631-663.

Miller D (1983) The correlates of entrepreneurship in three types of firms. Management Science 29(7): 770791.

Mom TJ, Chang Y-Y, Cholakova M, et al. (2019) A multilevel integrated framework of firm HR practices, individual ambidexterity, and organisational ambidexterity. Journal of Management 45(7): 3009-3034.

Mom TJ, Fourné SP and Jansen JJ (2015) Managers' work experience, ambidexterity, and performance: The contingency role of the work context. Human Resource Management 54(S1): 133-153.

Morgan RE and Berthon P (2008) Market orientation, generative learning, innovation strategy and business performance: Inter-relationships in bioscience firms. Journal of Management Studies 45(8): 1329-1353.

Mueller BA, Wolfe MT and Syed I (2017) Passion and grit: An exploration of the pathways leading to venture success. Journal of Business Venturing 32(3): 260-279.

Nosella A, Cantarello S and Filippini R (2012) The intellectual structure of organisational ambidexterity: A bibliometric investigation into the state of the art. Strategic Organization 10(4): 450-465.

OECD (1999) Business Incubation: International Case Studies. Paris: Organisation for Economic Co-Operation and Development.

O'Reilly CA and Tushman ML (2013) Organisational ambidexterity: Past, present, and future. Academy of Management Perspectives 27(4): 324-338.

Paytas J and Berglund D (2004) Technology Industries and Occupations for NAICS Industry Data. Pittsburgh, PA: Carnegie Mellon University Centre for Economic Development. Available at: https://ssti.org/reportarchive/NAICS_Tech1.pdf

Pfeffer J and Salancik GR (1978) The External Control of Organisations: A Resource Dependence Perspective. New York: Harper and Row.

Podsakoff PM, MacKenzie SB and Podsakoff NP (2012) Sources of method bias in social science research and recommendations on how to control it. Annual Review of Psychology 63: 539-569.

Podsakoff PM, MacKenzie SB, Lee J-Y, et al. (2003) Common method biases in behavioural research: A critical review of the literature and recommended remedies. Journal of Applied Psychology 88(5): 879-903.

Posch A and Garaus C (2020) Boon or curse? A contingent view on the relationship between strategic planning and organisational ambidexterity. Long Range Planning 53(6): 101878.

Ramachandran I, Lengnick-Hall CA and Badrinarayanan V (2019) Enabling and leveraging ambidexterity: Influence of strategic orientations and knowledge stock. Journal of Knowledge Management 23(6): $1136-1156$.

Rindfleisch A and Moorman C (2001) The acquisition and utilisation of information in new product alliances: A strength-of-ties perspective. Journal of Marketing 65(2): 1-18.

Sarkar MB, Echambadi R, Cavusgil ST, et al. (2001) The influence of complementarity, compatibility, and relationship capital on alliance performance. Journal of the Academy of Marketing Science 29(4): 358-373.

Schad J, Lewis MW, Raisch S, et al. (2016) Paradox research in management science: Looking back to move forward. Academy of Management Annals 10(1): 5-64.

Simsek Z (2009) Organisational ambidexterity: Towards a multilevel understanding. Journal of Management Studies 46(4): 597-624.

Simsek Z, Heavey C and Fox BC (2017) (Meta-)framing strategic entrepreneurship. Strategic Organization 15(4): 504-518. 
Simsek Z, Heavey C, Veiga JF, et al. (2009) A typology for aligning organisational ambidexterity's conceptualisations, antecedents, and outcomes. Journal of Management Studies 46(5): 864-894.

Sirmon DG, Hitt MA and Ireland RD (2007) Managing firm resources in dynamic environments to create value: Looking inside the black box. Academy of Management Review 32(1): 273-292.

Song XM and Parry ME (1997) A cross-national comparative study of new product development processes: Japan and the United States. Journal of Marketing 61(2): 1-18.

Song XM, Thieme RJ and Xie J (1998) The impact of cross-functional joint involvement across product development stages: An exploratory study. Journal of Product Innovation Management 15(4): 289-303.

Spigel B (2017) The relational organisation of entrepreneurial ecosystems. Entrepreneurship Theory and Practice 41(1): 49-72.

Stadler C, Rajwani T and Karaba F (2014) Solutions to the exploration/exploitation dilemma: Networks as a new level of analysis. International Journal of Management Reviews 16(2): 172-193.

Stettner U and Lavie D (2014) Ambidexterity under scrutiny: Exploration and exploitation via internal organisation, alliances, and acquisitions. Strategic Management Journal 35(13): 1903-1929.

Theodoraki C, Messeghem K and Rice MP (2018) A social capital approach to the development of sustainable entrepreneurial ecosystems: An explorative study. Small Business Economics 51(1): 153-170.

Tornikoski ET, Rannikko H and Heimonen TP (2017) Technology-based competitive advantages of young entrepreneurial firms: Conceptual development and empirical exploration. Journal of Small Business Management 55(2): 200-215.

Traynor K and Traynor S (2004) A comparison of marketing approaches used by high-tech firms: 1985 versus 2001. Industrial Marketing Management 33(5): 457-461.

Tukker A and Tischner U (2017) New Business for Old Europe: Product-Service Development, Competitiveness and Sustainability. London: Routledge.

Tushman ML and O'Reilly CA (1996) Ambidextrous organisations: Managing evolutionary and revolutionary change. California Management Review 38(4): 8-30.

Volery T, Mueller S and Von Siemens B (2015) Entrepreneur ambidexterity: A study of entrepreneur behaviours and competencies in growth-oriented small and medium-sized enterprises. International Small Business Journal 33(2): 109-129.

Voss GB and Voss ZG (2013) Strategic ambidexterity in small and medium-sized enterprises: Implementing exploration and exploitation in product and market domains. Organization Science 24(5): 1459-1477.

Voss GB, Sirdeshmukh D and Voss ZG (2008) The effects of slack resources and environmental threat on product exploration and exploitation. Academy of Management Journal 51(1): 147-164.

Wales WJ, Covin JG and Monsen E (2020) Entrepreneurial orientation: The necessity of a multi-level conceptualisation. Strategic Entrepreneurship Journal 14(4): 639-660.

Wales WJ, Wiklund J and McKelvie A (2015) What about new entry? Examining the theorised role of new entry in the entrepreneurial orientation-performance relationship. International Small Business Journal 33(4): 351-373.

Walrave B, Romme AGL, van Oorschot KE, et al. (2017) Managerial attention to exploitation versus exploration: Toward a dynamic perspective on ambidexterity. Industrial and Corporate Change 26(6): 11451160.

Wilden R, Hohberger J, Devinney TM, et al. (2018) Revisiting James March (1991): Whither exploration and exploitation? Strategic Organization 16(3): 352-369.

Withers MC, Ireland RD, Miller D, et al. (2018) Competitive landscape shifts: The influence of strategic entrepreneurship on shifts in market commonality. Academy of Management Review 43(3): 349-370.

Yin M, Hughes M and Hu Q (2020) Entrepreneurial orientation and new venture resource acquisition: Why context matters. Asia Pacific Journal of Management. Epub ahead of print 01 May. DOI: 10.1007/ s10490-020-09718-w

Zahra SA, Wright M and Abdelgawad S (2014) Contextualisation and the advancement of entrepreneurship research. International Small Business Journal 32(5): 479-500.

Zhang JA, Edgar F, Geare A, et al. (2016) The interactive effects of entrepreneurial orientation and capabilitybased HRM on firm performance: The mediating role of innovation ambidexterity. Industrial Marketing Management 59: 131-143. 
Zimmermann A, Raisch S and Cardinal LB (2018) Managing persistent tensions on the frontline: A configurational perspective on ambidexterity. Journal of Management Studies 55(5): 739-769.

\section{Author biographies}

Mathew Hughes is Professor of Entrepreneurship and Innovation at the School of Business and Economics, Loughborough University, UK. His research focused on the strategy and management of entrepreneurship, with a focus on entrepreneurial orientation, innovation, resources and social capital, and across a variety of organisational contexts. His research has been published in leading journals including Strategic Entrepreneurship Journal, British Journal of Management, Journal of Product innovation Management, Journal of World Business and Industrial Marketing Management. Mat is an Editor at the Entrepreneurship Research Journal and an Associate Editor at the Journal of Family Business Strategy and sits on several editorial review boards including the Journal of Business Venturing, Journal of Management Studies and British Journal of Management.

Paul Hughes is Professor of Strategic Management at Leicester Castle Business School, De Montfort University, UK. Paul researches strategic decision-making and improvisation, especially under conditions of high uncertainty. His research is published widely in internationally recognised outlets such as Journal of Product Innovation Management, Journal of World Business, Strategic Entrepreneurship Journal, British Journal of Management and Industrial Marketing Management.

Robert E Morgan Robert E Morgan (Ph.D., Cardiff University) holds the Sir Julian Hodge Chair and is a Professor of Marketing and Strategy at Cardiff University. He is a Strategy Research Foundation Scholar and hold visiting professorships including VU Universiteit Amsterdam and Copenhagen Business School. His research focuses on firm capabilities, new product development and technology management from a strategy perspective. His work has appeared in the British Journal of Management, Strategic Management Journal, Journal of Management Studies, Journal of the Academy of Marketing Science, Journal of Service Research, Strategic Entrepreneurship Journal and Journal of Product Innovation Management, among others.

lan R Hodgkinson is a Professor of Strategy at the School of Business and Economics, Loughborough University, UK. He is a multi-disciplinary scholar at the frontier of strategy research, investigating strategic decision-making in complex environments from individual to macro levels of analyses. Ian has published research articles in world-leading academic outlets such as Journal of World Business, Public Administration, International Journal of Operations \& Production Management, Public Management Review and Research Policy, among many others. Ian also serves as Associate Editor of Journal of Service Management (since 2015) and Associate Editor of European Journal of Marketing (since 2019).

Younggeun Lee is Assistant Professor of Entrepreneurship at the College of Business and Economics, California State University, Los Angeles, USA. His research focuses on entrepreneurial passion, corporate entrepreneurship and organizational innovation. Young's work has been published in such journals as International Small Business Journal, Journal of Business Venturing Insights and Corporate Social Responsibility \& Environmental Management. Young also serves as an Editor-in-Chief at the New England Journal of Entrepreneurship. 